\title{
Reproductive Behaviour of the Free-Living Marine Nematode Chromadorita tenuis
}

\author{
P. Jensen \\ Marine Biological Laboratory, University of Copenhagen, Strandpromenaden, DK-3000 Helsingör, Denmark
}

\begin{abstract}
Premating behaviour of the free-living marine nematode Chromadorita tenuis consists of movements of the male towards the adult virgin female stimulated by a pheromone released by the female. The vaginal gland cells are suggested as possible site of pheromone production. Sperm cells or an accompanying substance probably inhibit pheromone release after insemination. At close range, the attracted male shows pre-copulatory behaviour consisting of reverse locomotion which is not sexspecific since it also occurs between males. Mating itself consists of the male coiling the posterior part of the body around the female. The single ventral seta anterior to the male cloaca is suggested to act as receptor of mechanical stimuli (vibrations, touch) involved during, or preceding, mating. Insemination results in fertilization, egg shell formation, oviposition and loss of the capacity to attract males. Females mate only once during their life. Adult virgin females are continuously attractive to males; ovulation proceeds continuously; eggs are deposited in the proximal chambers of the uterus. There is no egg shell formation, nor are the unfertilized eggs deposited in the substrate; they are resorbed. At the age of $32 \mathrm{~d}$, virgin individuals of both sexes have as high a fecundity/fertilization capacity as newly matured $16-\mathrm{d}$ olds.
\end{abstract}

\section{INTRODUCTION}

While it is now well established that free-living nematodes are the most diverse, abundant and widespread marine metazoan taxon (Fenchel, 1978; Platt and Warwick, 1980), almost nothing is known about their reproductive mechanisms. For the first time we present here new pertinent information, based on results of laboratory experiments on Chromadorita tenuis, and attempt to relate structural properties with functional details during partnership events. Our results are not comparable to related studies on other marine species, but should be evaluated in the light of findings from parasitic and terrestrial nematodes.

The study is part of a project on the behaviour and ecology of Baltic Sea nematodes carried out at the Tvärminne Zoological Station, University of Helsinki, Finland

\section{MATERIAL AND METHODS}

Chromadorita tenuis (G. Schneider, 1906) was collected from 11 different submerged macrophytes (Jensen, 1979) from brackish waters in the vicinity of Tvär- minne Zoological Station, southern archipelago of Finland. Adult $C$. tenuis are about $1 \mathrm{~mm}$ in length; sexes are separate, reproduction continuous, and there is normally a sex ratio in the field of 1 male to 2 females. The nematode lives on submerged macrophytes, but in winter occurs sometimes in the detritus on the sea bottom (Jensen, 1981). Its food consists mainly of diatoms (Jensen, 1982). The species occurs in all European mesohaline waters

At low magnification, the sexes can be clearly differentiated at the fourth juvenile stage on the basis of both primary and secondary sexual characteristics. Body length and organic carbon contents also allow separation at the third juvenile stage. Differentiation between an old juvenile and a young adult is primarily based on presence or absence of a replacemental tooth in the buccal cavity and, more specifically whether or not the vulva of the female and the preanal supplements of the male are covered with cuticle. The reproductive systems are illustrated in Figs. 1 and 4

The female gonad consists of 2 opposed and reflexed ovaries, oviduct and uterus; it opens through the ventral vagina and vulva. The uterus consists of a central muscular chamber with 2 pairs of spermathecae and 2 proximal thinwalled chambers. Vaginal gland cells are 


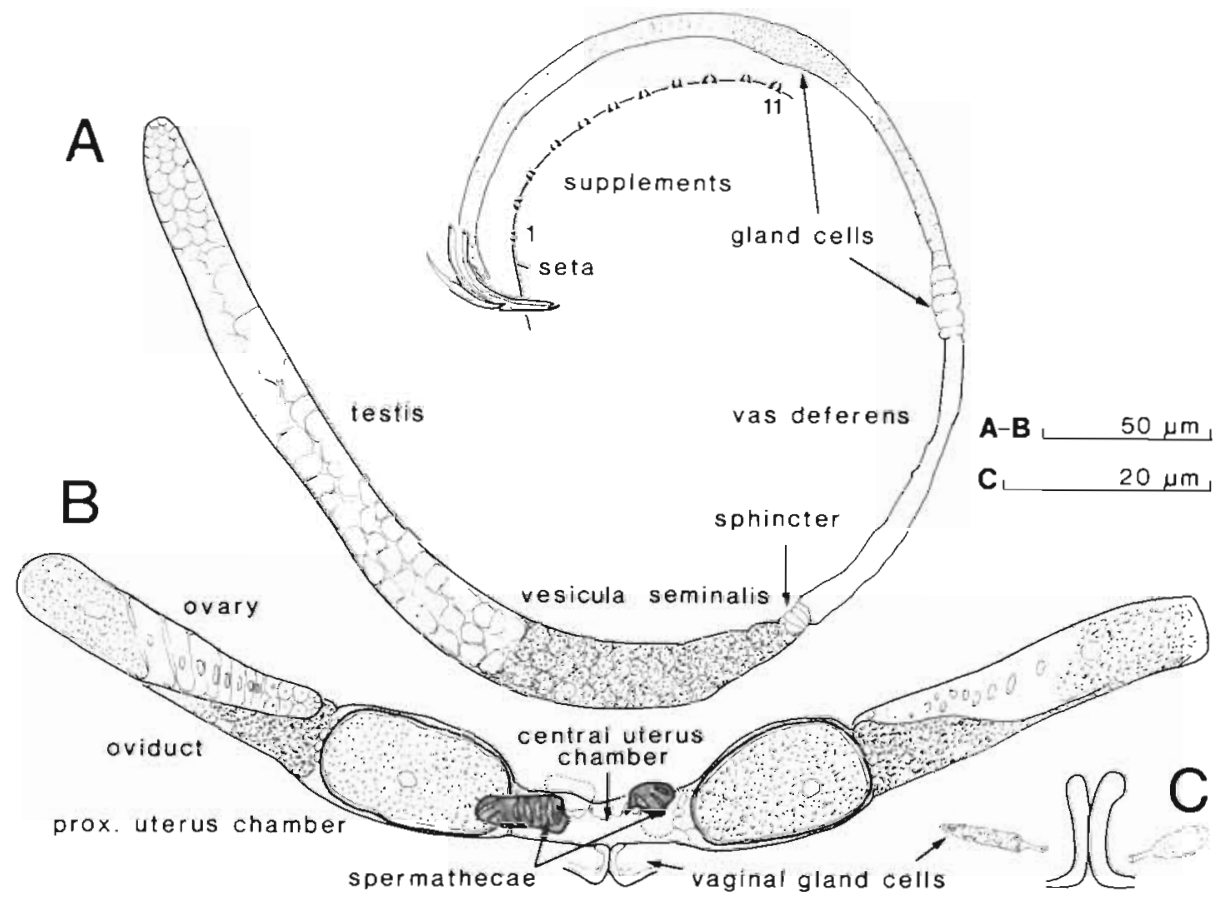

Fig. 1. Chromadorita tenuis. Right lateral views of gonads A male; B fertilized female; C vaginal region of adult virgin female

present, very difficult to detect in fertilized animals but fairly evident in adult virgin females: 1 pair on each side of the vagina, each emptying through a fine duct and pore subventrally close to the vulva (Fig. $1 \mathrm{C}$ ).

The male gonad consists of a single outstretched testis, a coarsely granulated vesicula seminalis, a sphincter and a vas deferens differentiated into 3 zones with 2 different types of glandular epithelia. It opens, together with the intestine, into a cloaca at the ventral side. The copulatory apparatus consists of 2 curved spicules, each with a guiding piece (gubernaculum). In front of the cloaca, 11 ventral cup-shaped supplements are present, together with a single small stout seta just in front of the cloaca.

Nematodes were kept alive temporarily in small dishes with natural sea water and vegetation and longterm cultivated on a $0.8 \%$ Agar inocculated with the pennate diatom Nitzschia sp. (Jensen, 1982). By 1980/ 81 , the information accumulated on the factors controlling the whole life span of Chromadorita tenuis permitted laboratory experiments to be carried out - using a large stock of eggs and individuals with known life history - independent of the season. Such stocks were used herein as well as original field material from and subsequent to $1978 / 79$.

Sexual attraction experiments were conducted on sterile Agar plates $8.4 \mathrm{~cm}$ in diameter; 25 fertilized and 25 virgin adult females were incubated for $24 \mathrm{~h}$ in separate sterile Agar batches in order to produce "female agar". Knowing that previously identified pheromones are waterbome (Jones, 1967; Bone and Shorey, 1978) a small portion of this "fertilized female agar" and "virgin female agar" was then used as attractants. A 24 -h incubation is sufficient to produce a sexual response. Attraction of the male is elicited by the mature virgin female - not vice versa and not among specimens of the same sex. We used 25 mated males to test sex attractants released from the two types of "female agar". The males were placed together in the centre of the disc and allowed to migrate in all directions. The bottom of the disc was divided into 6 zones to the left and to the right of the inocculum. The "female agar" or the control was inocculated in Zone 4 . The position of individual males was recorded 1, 2 and 3 h later. Each set of experiments was repeated 4 times with new individuals and dishes. The use of mature males, raised isolated from egg or first juvenile stage, often spoiled the experiments since many such individuals started pre-copulatory and mating behaviour with each other in the inocculum and did not migrate.

\section{RESULTS}

\section{Virginity}

Males of Chromadorita tenuis are specifically attracted to neither "fertilized female agar" nor to the control (Fig. 2 A). The males did not move very much. Only a few individuals migrated far away from the centre, but never into a patch. "Virgin female agar" strongly attracted males, independent of a control or "fertilized female agar" (Figs. $2 \mathrm{~B}-\mathrm{C} ; 3 \mathrm{~A})$. This 
response was observable after $1 \mathrm{~h}$. After $3 \mathrm{~h}$, all males were found in the left part of the dish containing "virgin female agar", and more than $80 \%$ of the males were found inside this inocculum. The males continuously moved about within this patch, but no precopulatory behaviour or mating behaviour were observed.

In 2 additional tests, 20 fertilized females plus 1 young mature, virgin female were kept together in a small dish with natural sea water and vegetation. A male was introduced. Apparently, it moved randomly not taking notice of the females. However, after about $1 \mathrm{~h}$ the male was so close to the virgin female that his

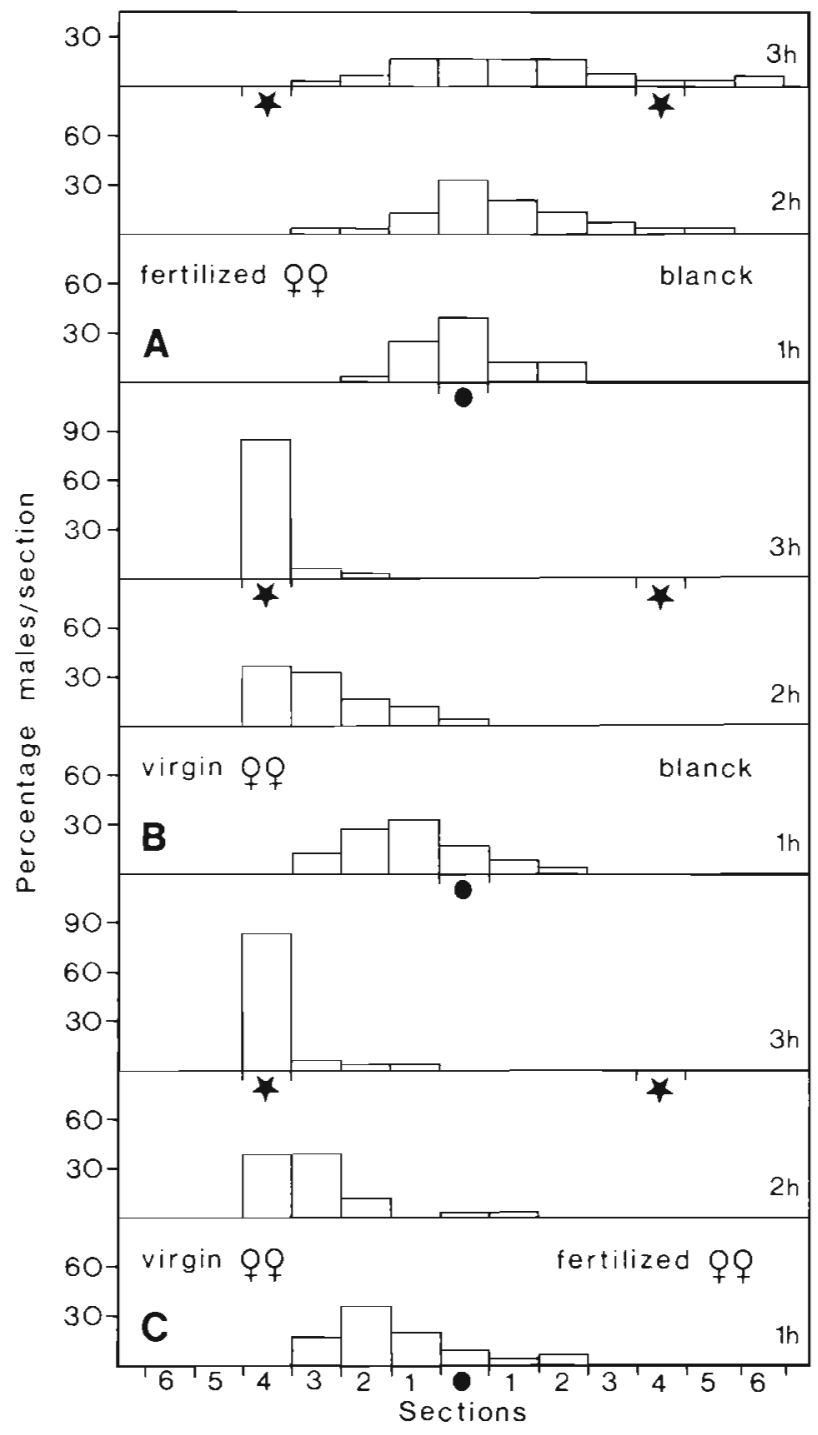

Fig. 2. Chromadorita tenuis. Distribution of male specimens in sectors of an Agar dish after 1,2 and $3 \mathrm{~h}$ of testing attractive stimuli from fertilized females (A), adult virgin females (B). both (C). Section 0: inocculation zone of males; Section 4: inocculation zone of female material. Each histogram is the mean of 4 replicates locomotion pattern drastically changed into precopulatory behaviour, followed by mating. The movement of the male towards the virgin female strongly indicates the release of a female-virgin substance and a perception of this substance of the male. Candidates for receptors are the amphids and setae or papillae of the cephalic sense organs.

A virgin female of Chromadorita tenuis is structurally characterized by distinct vaginal-gland cells accompanied with ducts emptying along subventral pores close to the vulva (Fig, 1 C). Spermathecae are indistinct. Sometimes many, irregularly-shaped eggs are present in the uterus (Fig. 4 C). They do not have a distinct shell, but the walls of the central uterus chamber are very distinct although the uterus volume is small (Fig. $4 \mathrm{C}$ ). When a virgin female is continuously kept isolated, the egg situated most distally in each proximal chamber, i. e. the first one released from the ovary, changes its colour from dark to pink. High magnification reveals that the contents of these eggs disappear (Fig. 4 C).

\section{Pre-Copulatory Behaviour}

The pre-copulatory behaviour is defined here as backwards movement of the male body and ventral curving of its tail (Fig. $3 \mathrm{~B}-\mathrm{C}$ ). No movements of the copulatory apparatus were observed. This type of precopulatory behaviour may be repeated several times. Movement of the female seems not to be influenced. The same behaviour is also observed when virgin males are brought together, suggesting that a sexspecific substance is not involved. Since the partners do not have physical contact with each other during this premating stage, tactile responses also seem to play no role. This leaves vibrations caused by the partner as the most plausible stimulus. Along the entire length of the body, 4 rows of somatic setae and pores are present, and ventrally in front of the cloaca 2 special types of sense organs: a single small stout seta and 11 cup-shaped supplements (Fig. 1 A). At present, it is not possible to decide whether these organs play a role as receivers of vibratory stimuli. However, it seems reasonable to search for such a site along the posterior body of the male, since the pre-copulatory behaviour is fully centred along this part of the body

\section{Mating Behaviour}

Moving backwards, the male coils its tail around the posterior part of the female body (Fig. 3 D). In the following seconds, the loop consists of $2 / 2-3$ turns. It is 
accomplished by continued backward moving of the male body. Apparently in order to locate the vulva, the male continues to spiral around the female body, although the number of turns remains constant. This spiralling is often interrupted while the female may continue to feed. The male seems to be fully occupied with mating activities. Unfortunately, during spiralling it was not possible to observe any possible actions of supplements, single seta or copulatory apparatus.

Spiralling and female gliding within the coil is stopped when the male inseminates (Fig. 3 E). Both partners hardly move at all during insemination, apart from a few head movements. Insemination lasts 3 to 5 min; it is terminated by the female initiating wriggling and twisting. While the male does not uncoil, the female glides forward so that the male must release any contact of preanal supplements.

The female is inseminated only once in her life; this results in 1 brood. We have tested this several times, using different male densities around a female which had mated before, and different temperatures and time schedules of illumination simulating different seasons.

Isolated males were sometimes observed coiling their tail around their own oesophageal region, with the body moving therein for a few seconds. When previously isolated males were brought together, their initial pre-copulatory behaviour also developed into mating behaviour with coiling. However, in most cases the advancing partner was rejected very soon.

The 11 cup-shaped supplement of the male most likely facilitate close contact with the female during search for her vulva and during mating. Since the ventral seta of the male must necessarily touch the female during coiling, it is possible that it acts as tactile receptor for the vulva, and thus evokes spicule movements when the vulva is located.

On attaining maturity no differences were observed in the male's reproductive system independent of its life history.

A newly inseminated female has all 4 spermathecae filled (Figs, $1 \mathrm{~B} ; 3 \mathrm{~F} ; 4 \mathrm{~A}$ ); also its central uterus chamber is expanded and totally filled with very finely granulated sperm cells and possibly an additional substance. No sperm cells or other materials were observed in the proximal uterus chambers. Sometimes sperm cells were left on the vulva in the form of a muccous mass, but more often this substance was released by the female after she had emptied the sperm mass from the central uterus chamber in the substrate.

Fertilized eggs are oval and have an ornamentated shell (Figs. $1 \mathrm{~B} ; 4 \mathrm{~B}$ ). They were never observed in the oviducts. Eggs are stored in the proximal uterus chambers. The eggs become strongly deformed when they pass through the closing cells between proximal chamber and central chamber and through the vagina. This process is completed within seconds. Eggs were never observed in the central uterus chamber of fixed females. Mostly, only 1 fertilized egg is present in 1 or in each of the 2 proximal chambers. On 2 occasions a fertilized egg was obversed deposited in the substrate, where it became more spherical.

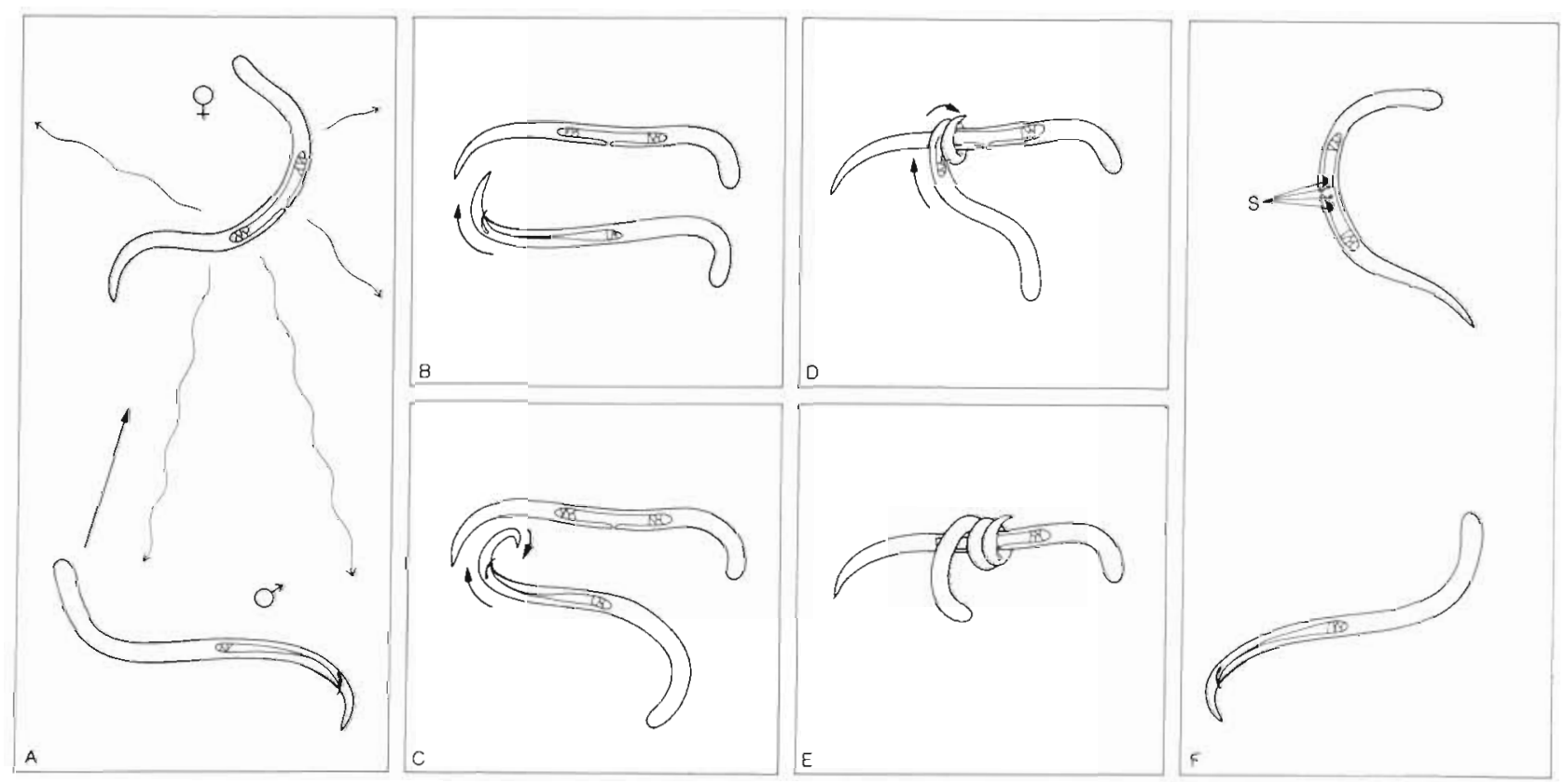

Fig. 3. Chromadorita tenuis. Sequence of events in sexual behaviour. A sexual attraction at long distance; B-C pre-copulatory behaviour; $D-E$ mating behaviour; $F$ disintegration (S: spermathecae). Not to scale 

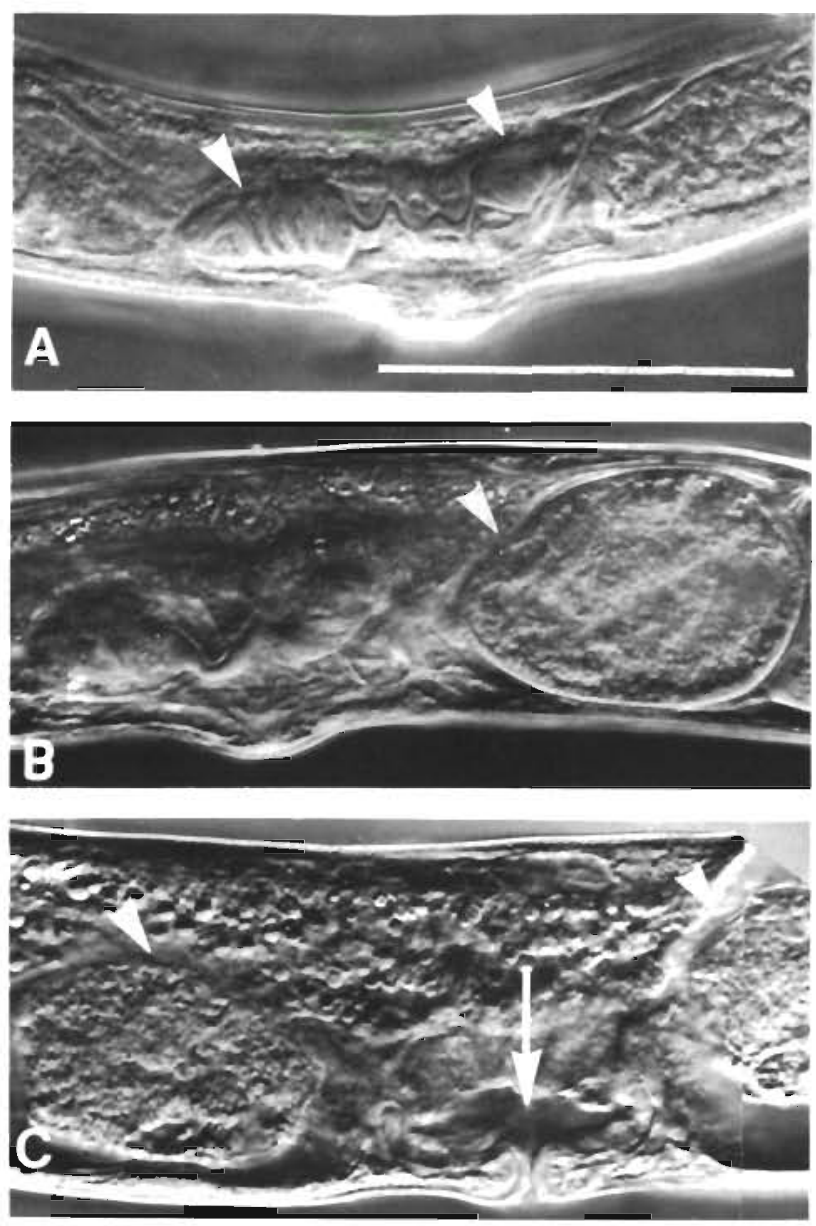

Fig. 4. Chromadorita tenuis. Right lateral views of the female reproductive system. A filled spermathecae; $B$ fertilized egg in the proximal uterus chamber; $C$ central uterus chamber and 1 egg in each proximal uterus chamber in an adult virgin. Scale $=50 \mu \mathrm{m}$

\section{Fecundity and Fertilization Capacity}

In order to test the fecundity of isolated 32-d old (from time of deposition) virgin females and the fertilization capacity of 32 -d old virgin males they were mated as well as with newly matured 16-d old males and females. The 32-d old virgin individuals were not significantly different in their capacity to fertilize and produce offspring. The duration from insemination to the first egg laid was slightly higher in old females compared to newly matured females, 2.9 -d versus $2.0 \mathrm{~d}$ at $18^{\circ} \mathrm{C}$.

\section{DISCUSSION}

The results presented strongly support the hypothesis of Greet (1964) that sexual attraction and copulation are independent events requiring separate stimuli. The attracting substance, a pheromone (Bone and Shorey, 1978), released by the adult virgin female of Chromadorita tenuis is sex-specific and serves only to bring the males close to her, after which other stimuli take over. C. tenuis has a distinct pre-copulatory behaviour: initiating mating the male moves backwards ("reversing" sensu Croll, 1971) coiling its tail and posterior body, without physical female contact. The stimulus evoking this behaviour is not sexspecific (some males also elicite this behaviour). Presumably, vibratory stimulation is involved. The stimulus evoking the mating behaviour is clearly tactile: physical contact immediately triggers the backwards coiling of the male tail around the partner. Since in this phase the male does not make any distinction between the sex of the partner, it is likely that no chemical compounds are involved.

Marchant (1970), Cheng and Samoiloff (1972) and Bone et al. (1978) provided evidence that the female reproductive system is the site of pheromone production. However, Croll and Wright (1976) failed to confirm Marchant's results. The findings reported here also support that the female reproductive system is the site of pheromone production, probably the vaginal gland cells of adult virgins (Fig. 1 C, Table 1). While this conclusion is based on microscopical observations and on the fact that only virgin females of Chromadorita tenuis attract males, sperm cells and additional substances released by males inhibit further pheromone production after copulation, either because the substances enter the pores of the vaginal gland cells or simply by blocking the pores. The female receive far more sperm cells during insemination than can be stored in her spermathecae; also her central uterus chamber is filled, but soon afterwards this sperm mass is rejected through the vulva and may, in this way, come in contact with the pores of the vaginal gland cells.

Following copulation in the plant-parasitic nematode Scutellonema cavenessi Sher, 1964, Demeure et al. (1980) observed a mucus-like plug on the vulva. Unfortunately, it is not clear whether this was due to male activities after copulation or to the sperm mass released from the female as in Chromadorita tenuis.

Green and Greet (1972) suggested the hypodermal gland cells as site for pheromone production; especially the body surface of the postvulvar region was shown to release pheromones. Chromadorita tenuis also has hypodermal gland cells associated with cuticular pores along the body, although their presence in both sexes does not support sex-specific characteristics. However, it could be that the 2 pairs of vaginal gland cells in $C$. tenuis are just modified hypodermal gland cells 
The precise location of pheromone receptors in the male remains unknown. Two possible sites have been proposed: the tips of the spicules (Clark et al., 1973; Samoiloff et al., 1973) and the cephalic nerve fibres (Ward, 1973; Croll, 1977). However, as pointed out by Bone and Shorey (1978), it is likely that anterior chemoreceptors control orientation toward a pheromone source from a distance, and that posteriorly located receptors control short-range copulatory reactions. The results reported here strongly support the above hypothesis. At some distance from the female, the behaviour of Chromadorita tenuis male is very different from that at close range. It is doubtful whether the tips of the spicules act as receptors for the precopulatory stimulus in $C$. tenuis since they were never observed protruding or moving at all during this event. Tips of the spicules are known from other studies to play a role while searching for the vulva (Chitwood and Chitwood, 1950; Greet, 1964; Chin and Taylor, 1964; Lee, 1973; Clark et al., 1973), but neither von Thun (1968) nor we were able to observe the spicules during coiling around the female body. SEM photographs of $C$. tenuis may provide new information about specific pores on the spicules or on the ventral border of the tail not observable by light microscopy, as shown by Clark et al. (1973) and Clark and Shepherd (1977). The ventral seta located just in front of the cloaca in $C$. tenuis (Fig. $1 \mathrm{~A}$ ) is a possible receptor site for vibratory and tactile stimuli during the pre-copulatory behaviour and/or during mating. This seta, found only in males, is shorter and stouter than other somatic setae on the body and its position is unique, indicating a specific function.

Insemination of sperm cells and possibly of additional substances from the vas deferens (Fig. 1 A) causes not only fertilization of the eggs and stops the female's attractiveness to males, but triggers other mechanisms in the reproductive system of Chromadorita tenuis, compared to a virgin female (Table 1). Both types of females produce eggs from the time of maturation. Since eggs were never oberved in the oviducts, the period from ovulation to egg deposition in the proximal uterus chambers is very short, therefore fertilization presumably takes place in the proximal chambers in addition to the formation of a definite ornamentated egg shell. However, the problem then arises as to how sperm cells from the presumed spermathecae in the central uterus chamber enter the proximal chambers to fertilize the eggs. Indeed, one would expect the spermathecae opening at the junction between the oviduct and the proximal chamber, fertilizing the eggs when passing from the ovary. Structurally, this might be deduced to be the case in the majority of Chromadoridae observed, but these species do not have the 4 distinct pouches in the central uterus chamber as found in $C$. tenuis and also in C. guidoschneideri (Filipjev, 1929) (unpubl. obs.). In C. tenuis there are some (6?) irregularly shaped and grouped cells at the junction between the oviduct and the proximal uterus chamber and the central chamber; these cells form without any doubt the closing mechanism and are not a store for sperm cells (Fig. 1 B)

Virgin females do not form a shell around the nonfertilized eggs in the proximal uterus chambers. They do not release the energy stored in the eggs by depositing them in the substrate, although ovulation continues and food conditions are favourable. The contents of the eggs are resorbed in the proximal chambers. This can be observed as a colour change of the eggs and a slow disappearence of the contents (Fig. 4 C), rather similar to the observations in Dipetalonema viteae (Chabeaud, 1952) Johnson et al. (1974) and Panagrellus redivivus Goodey by Duggal (1978). Such a mechanism can be of great energetic advantage.

Jennings and Deutsch (1975) thought to have found in matured female specimens of a closely related species (both regarding taxonomy and trophic type), Chromadorina germanica (Bütschli, 1874), a high arylamidase activity in a spermatheca, which they interpreted to indicate absorbtion of sperm cells left over

Table 1 Chromadorita tenuis. Supposed trigger mechanisms involved in female reproductive system upon insemination or virginity

\begin{tabular}{|c|c|c|c|c|c|c|c|c|}
\hline \multirow{3}{*}{$\begin{array}{l}\text { Location } \\
\text { Event }\end{array}$} & \multirow{3}{*}{$\begin{array}{c}\text { Ovary } \\
\text { Ovulation }\end{array}$} & \multirow{3}{*}{$\begin{array}{c}\text { Oviduct } \\
\text { Fertilization }\end{array}$} & \multicolumn{5}{|c|}{ Uterus } & \multirow{3}{*}{$\begin{array}{l}\text { Vaginal } \\
\text { gland cells } \\
\text { Sex } \\
\text { pheromone } \\
\text { production }\end{array}$} \\
\hline & & & \multicolumn{4}{|c|}{ Proximal chambers } & \multirow{2}{*}{$\begin{array}{c}\text { Central } \\
\text { chamber } \\
\text { Oviposition }\end{array}$} & \\
\hline & & & $\begin{array}{l}\text { Fertili- } \\
\text { zation }\end{array}$ & $\begin{array}{c}\text { Egg } \\
\text { shell } \\
\text { formation }\end{array}$ & $\begin{array}{c}\mathrm{Egg} \\
\text { presence }\end{array}$ & $\begin{array}{l}\text { Egg } \\
\text { reab- } \\
\text { sorbtion }\end{array}$ & & \\
\hline $\begin{array}{c}9 \\
\text { (inseminated) }\end{array}$ & + & $?$ & + & + & + & - & + & - \\
\hline $\begin{array}{c}9 \\
\text { (virgin) }\end{array}$ & + & & & - & + & + & - & + \\
\hline
\end{tabular}


from an earlier copulation. However, it seems strange that only one spermatheca should have been observed, because spermathecae normally are paired in Chromadoridae. Could it be that Jennings and Deutsch in reality stained an unfertilized egg? Then the speculation of Warwick (1981) has no basis, that energy from surplus sperm helps the female to produce eggs. This would imply repeated copulations, which have never been observed in this material of Chromadorita tenuis nor by Tietjen and Lee (1973) in the related species Chromadora macrolaimoides Steiner, 1915.

Acknowledgements. Laboratory assistance by Miss E. Leskinen and research facilities at the Tvärminne Zoological Station, University of Helsinki, Finland and fruitfull discussions with Dr. S. A. Gerlach are highly appreciated. Dr. H. M. Platt kindly revised the English manuscript. The study was supported by grants from the Natural Science Faculty, University of Copenhagen and the Danish Natural Science Research Council.

\section{LITERATURE CITED}

Bone, L. W., Shorey, H. H. (1978). Nematode sex pheromones. J. chem. Ecol. 4: 595-612

Bone, L. W., Shorey, H. H., Gaston, L. K. (1978). Nippostrongylus brasiliensis: factors influencing male movement toward a female pheromone source. Expl. Parasit. 44: $100-108$

Cheng, R., Samoiloff, M. R. (1972). Effects of cyclohexamide and hydroxyurea on mating behaviour and its development in the free-living nematode Panagrellus silusiae. Can. J. Zool. 50: 333-336

Chin, D. A., Taylor, D. P. (1969). Sexual attraction and mating patterns in Cylindrocorpus longistoma and C. curzix (Nematoda: Cylindrocorpidae). J. Nematol. 1: 313-317

Chitwood, B. G., Chitwood, M. B. (1950). An introduction to nematology, B. B. Chitwood, Baltimore, Maryland

Clark, S. A., Spepherd, A. M. (1977). Structure of the spicules and caudal sensory equipment in the male of Aphelenchoides blastophthorus (Nematoda: Tylenchida, Aphelenchina). Nematologica 23: 103-111

Clark, S. A., Shepherd, A. M., Kempton, A. (1973). Spicule structure in some Heterodera spp. Nematologica 19: 242-247

Croll, N. A. (1971). Movement patterns of ineffective larvae of Trichonema spp. in non-directional light. Parasitology 62: $467-478$

Croll, N. A. (1977). Sensory mechanisms in nematodes. A. Rev. Phytopathol. 15: 75-89

Croll, N. A., Wright, K. A. (1976). Observations on the movement and structure of the bursa of Nippostrongylus brasiliensis and Nematospiroides dubius. Can. J. Zool. 54: $1466-1480$

Demeure, Y., Netscher, C., Quénéhervé, P. (1980). Biology of the plant-parasitic nematode Scutellonema cavenessi Sher, 1964: reproduction, development and life cycle.
Revue Nématol. 3: 213-225

Duggal, C L. (1978) Initiation of copulation and its effect on oocyte production and life span of adult female Panagrelhus redivivus. Nematologica 24: 269-276.

Fenchel, T M. (1978). The ecology of micro- and meiobenthos. Rev. Ecol. Syst. 9: 99-121

Green, C. D., Greet, D N. (1972). The location of the secretions that attract male Heterodera schachtii and $H$. rostochiensis to their females. Nematologica 18: 347-352

Greet, D. N. (1964). Observations on sexual attraction and copulation in the nematode Panagrolaimus rigidus (Schneider). Nature, Lond. 204: 96-97

Jennings, J, B., Deutsch, A. (1975). Occurence and possible adaptive significance of $B$-glucoronidase and arylamidase ("leucine aminopeptidase") activity in two species of marine nematodes. Comp. Biochem. Physiol. 52 A: 611-614

Jensen, P. (1979). Nematodes from the brackish waters of the southern archipelago of Finland. Phytal species. Ann. Zool. Fennici 16: 281-285

Jensen, P. (1981). Phyto-chemical sensitivity and swimming behaviour of the free-living marine nematode Chromadorita tenuis. Mar. Ecol. Prog. Ser 4: 203-206

Jensen, P. (1982). Diatom-feeding behaviour of the free-living marine nematode Chromadorita tenuis. Nematologica, in press

Johnson, M. H., Orihel, T C., Beaver, P. C. (1974). Dipetalonema viteae in the experimentally infected jird, Meriones unguiculatus. I. Insemination, development from egg to microfilaria, reinsemination, and longevity of mated and unmated worms. J. Parasitol. 60: 302-309

Jones, T P (1967). Sex attraction and copulation in Pelodera teres. Nematologica 12: 518-522

Lee, D. L. (1973). Evidence for a sensory function for the copulatory spicules of nematodes. J. Zool. Lond. 169: $281-285$

Marchant, H. J. (1970). Bursal response in sexually stimulated Nematospiroides dubius (Nematoda). J. Parasitol. 56: 201-202

Platt, H. M., Warwick, R. M. (1980). The significance of freeliving nematodes to the littoral ecosystem. In: Price, J. H. Irvine, D. E. G., Farnham, W. F. (eds.) The shore environment, Vol. 2, Ecosystems. Systematic Association, Spec. Vol. 17 (b). Academic Press, London, pp. 729-759

Samoiloff, M. R., MeNicholl, P., Cheng, P., Balakanich, S (1973). Regulation of nematode behaviour by physicalmeans. Espl. Parasit. 33: 253-262

von Thun, W. (1968). Autoökologische Untersuchungen an freilebenden Nematoden des Brackwassers. Ph. D. thesis, Kiel University

Tietjen, J. H., Lee, J. J. (1973). Life history and feeding habits of the marine nematode Chromadora macrolaimoides Steiner Oecologia 12: 303-314

Ward, S. (1973). Chemotaxis by the nematode Caenorhabditis elegans: identification of attractants and analysis of the response by use of mutants. Proc. natn. Acad Sci. U. S. A. 70: $817-821$

Warwick, R. M. (1981). The influence of temperature and salinity on energy partitioning in the marine nematode Diplolaimelloides bruciei. Oecologia 51: 318-325 